\title{
Essais
}

ESSAIS

Revue interdisciplinaire d'Humanités

$10 \mid 2016$

Faire-valoir et seconds couteaux

\section{When the second becomes number one: vice- presidential power in foreign and defense policy in the twenty-first century}

\section{Christopher Griffin}

\section{(2) OpenEdition \\ Journals}

Electronic version

URL: http://journals.openedition.org/essais/4058

DOI: 10.4000/essais.4058

ISSN: 2276-0970

Publisher

École doctorale Montaigne Humanités

\section{Printed version}

Date of publication: 15 September 2016

Number of pages: 131-145

ISBN: 978-2-9544269-9-0

ISSN: $2417-4211$

\section{Electronic reference}

Christopher Griffin, «When the second becomes number one: vice-presidential power in foreign and defense policy in the twenty-first century », Essais [Online], 10 | 2016, Online since 15 October 2020, connection on 21 October 2020. URL : http://journals.openedition.org/essais/4058 ; DOI : https:// doi.org/10.4000/essais.4058 


\title{
When the second becomes
}

\section{number one: vice-presidential \\ power in foreign and defense policy in the twenty-first century}

\author{
Christopher Griffin
}

It is somewhat misleading to refer to the US Vice President as the "sidekick" of the President, as that was never the purpose of the position. The Vice President was never intended to be the closest advisor to the president. The position has always been much further down the chain of command. John Adams, the first Vice President, called it "the most insignificant office that ever the invention of man contrived," and it was initially a sort of consolation prize for the runner-up in presidential elections. The Vice President was not considered as part of the executive branch until the twentieth century, as the position as the President of the Senate was considered to be a legislative branch responsibility. ${ }^{2}$ Vice Presidents were not allowed even to sit in on cabinet meetings until $1921 .^{3}$

It was a surprise, therefore, to read headlines such as "Is this the real president of the United States?," with a photo of the Vice President in the Guardian in July 2007. ${ }^{4}$ An entire literature exists that claims that Richard Cheney was in fact the real president during the George W. Bush administration. ${ }^{5}$ It is clear that Cheney was the most powerful Vice President to date, and that he wielded considerable influence in the Bush administration. A key example, albeit in particular circumstances, was Cheney's order to the military to shoot

1 Cited in Goldstein, Joel K., "The Rising Power of the Modern Vice Presidency," Presidential Studies Quarterly 38 (2008): p. 374.

2 Relyea, Harold C., "The Law: The Executive Office of the Vice President: Constitutional and Legal Considerations," Presidential Studies Quarterly 40 (2010): p. 328.

3 Albert, Richard, "The Evolving Vice Presidency," Temple Law Review 78 (2005): p. 832.

4 Pilkington (Ed.), "Is this the real president of the United States?," Guardian, 23 Jul. 2007.

5 See for example: Nichols, John, Dick: The Man Who Is President (New York: The New Press, 2004), Goldsmith, Jack, "How Cheney Reined in Presidential Power," New York Times, 15 Sep. 2011, Kattner, Robert, "Cheney’s Unprecedented Power," Boston Globe, 25 Feb. 2009, Warshaw, Shirley Anne, The Co-Presidency of Bush and Cheney (Stanford: Stanford University Press, 2009). 
down civilian airliners heading for Washington on 11 September $2001 .^{6}$ This was clearly an order that fell outside vice-presidential authority. In an influential article in the New York Times in 2003, Elisabeth Bumiller and Eric Schmitt argued that Cheney's extraordinary power was concentrated in three policy areas: national security, homeland defense, and the economy. ${ }^{7}$

This paper will focus in on the first policy area, national security, and examine two related questions. First, how did Cheney become such a powerful leader in foreign and defense policy? Second, how did his power in this issue area evolve during his vice-presidency? This paper argues that Cheney's leadership in foreign and defense policy was not at odds with President Bush, who indeed likely facilitated Cheney's rise. I also put forth the proposition that a relatively unexplored reason for Cheney's power in national security was his close relationship with Secretary of Defense Donald Rumsfeld. ${ }^{8}$ The duo Cheney-Rumsfeld were able to put considerable pressure on the rest of the Bush's decision-making team to impose their particular worldview, especially regarding the decision to go to war in Iraq and on issues of counter-terrorism. When Rumsfeld left office in 2006, Cheney's influence appears to have declined to a certain degree, which indicates that the Secretary of Defense was at least in part important for vice-presidential power.

This paper will first briefly address the well-known changes in the vicepresidency that led to increased power in the position since 1945, which provided a precedent for Cheney's influence in the Bush administration. The paper will then examine the issue areas where Cheney appears to have had decisive impact, most notably the war in Iraq and counter-terrorism policy, and his relationship with Rumsfeld. Finally, the paper will consider what we know about Cheney's influence in the Bush administration after 2006.

\section{Vice Presidential Power since 1945}

A common starting point to discuss the rise of vice presidential power, especially in national security, is with Harry Truman. Truman, on becoming president after Roosevelt's death in April 1945, admitted to having little knowledge regarding the US's military strategy in World War II, and had not been informed about the Manhattan Project. ${ }^{9}$ After becoming president,

6 Cheney, Dick and Cheney, Liz, In My Time: A Personal and Political Memoir (New York: Threshold Editions, 2011): p. 3.

7 Bumiller, Elisabeth and Schmitt, Eric, "Cheney, Little Seen By Public, Plays a Visible Role for Bush," New York Times, 31 Jan. 2003.

8 See also the documentary film The Unknown Known: The Life and Times of Donald Rumsfeld, 2013, which is a long interview with the former secretary about his life and his decisions during the Bush administration.

9 Kengor, Paul, "The Vice President, Secretary of State, and Foreign Policy," Political Science Quarterly 115 (2000): p. 175. 
Truman attempted to partially remedy the situation by appointing his own Vice President to a position on the new National Security Council (NSC) in 1949. Truman wanted to give the Vice President an idea of what was going on in the national security arena should he be called to take over the leadership of the country. ${ }^{10}$ It was clearly necessary to have a ready and informed successor available in case the president was killed in a surprise nuclear attack. ${ }^{11}$

What is important to note, and would later also be crucial for the rise of Cheney's influence, was that vice presidential power increased at the same time as that of the president. According to historian Joel Goldsmith, there were three major changes that provided the Vice President with more power in the 1960s and 1970s. First, Richard Nixon decided that the the Vice President needed more responsibility in foreign policy. ${ }^{12}$ This change should be taken with a grain of salt, however, as any Vice President, no matter how powerful, would have been overshadowed in the realm of national security by Henry Kissinger, who combined the office of National Security Advisor and Secretary of State. Second, the Vice President became a real contender for the presidency. ${ }^{13}$ Senator and 2008 presidential candidate John McCain, however, claimed in 2004 that the vice presidency was a waste of time, and compared it to his experiences in a North Vietnamese prison camp. ${ }^{14}$ Third, President Jimmy Carter became the first president to delegate significant powers to his Vice President, Walter Mondale, and made a number of structural changes that effectively made Mondale a primary advisor and part of the executive branch. ${ }^{15}$ Mondale's Chief of Staff, Richard Moe, stated that "Carter put Mondale in the chain of command," where he had some responsibilities in the field of national security, including renewing relations with Vietnam in the aftermath of the war. ${ }^{16}$

Vice presidential influence in foreign policy was not completely unprecedented, even if the extent of Cheney's power surpassed that of all of his successors. George H.W. Bush was given the job of investigating US efforts to combat terrorism in 1986 after attacks by Libya in Europe. ${ }^{17}$ Vice Presidents

10 Relyea p. 329.

11 This would seem to have been Truman's initiative (or irritation at having been kept out of the loop), as danger to the president through assassination was nothing new.

12 Goldstein, "The Rising Power of the Modern Vice Presidency", p. 376.

13 Goldstein, "The Rising Power of the Modern Vice Presidency", p. 376.

14 Sandalaw, Marc, "Golden Age of the Second Banana/US Vice Presidency Rises from Anonymity to Become One of World's Most Powerful Jobs," SF Gate, 4 Jul. 2004.

15 Goldstein, "The Rising Power of the Modern Vice Presidency" p. 377-378.

16 Moe, Richard, "The Making of the Modern Vice Presidency. A Personal Reflection," Presidential Studies Quarterly 38 (2008): 398.

17 Ronald Reagan, "The National Program for Combating Terrorism," National Security Decision Directive Number 207, National Security Archive, September 11 Sourcebooks, Vol. I, 20 Jan. 1986. 
Dan Quayle and Al Gore also wielded increased power in foreign policy. Paul Kengor claims that Quayle's influence was reduced due to his rocky relationship with Secretary of State James Baker, despite the Vice President's considerable expertise in national security issues. ${ }^{18}$ Cheney, however, manifested considerable respect for Quayle while the former was Secretary of Defense. ${ }^{19}$ Kengor also argues that Gore's increased foreign policy power came in part due to his close relationship with Secretaries of State Warren Christopher and Madeleine Albright, who allowed Gore to influence Russian policy. ${ }^{20}$

Roy Brownell points out the extent to which the position of the Vice President is independent. As the Vice President is technically elected by the public, he or she cannot be fired by the President, and thus can take positions or actions opposed to the administration. ${ }^{21}$ Brownell demonstrates that Vice Presidents, unlike the popular perception, have frequently defied their receptive Presidents throughout American history. Cheney opposed Bush on four occasions: the weapons inspectors in Iraq, gay marriage, Senate rules on the filibuster, and litigation on the Second mendment of the Constitution. ${ }^{22}$ Thus, the Vice President is not always relegated to a sidekick position, and has a great deal of protection against sanctions coming from the executive branch. ${ }^{23}$

\section{Vice President Cheney and National Security}

The power of the executive branch in foreign policy is one that has stimulated considerable debate. One of the problems is the contention over the term "Commander in Chief," which many Presidents have taken to mean that the executive can make most major decisions regarding war and diplomacy. ${ }^{24}$ While most scholars argue that the President does not in fact have full power over the formulation of foreign policy, it is clear that the Bush administration gained considerable powers in the area through Congressional authorizations for the use of force in 2001 and 2002. ${ }^{25}$ Congress gave Bush the power to fight terrorism and Iraq in the way that the executive branch wanted, which was

18 Kengor p. 185-187.

19 Kengor p. 193.

20 Kengor p. 194-195.

21 Brownell, Roy E., “The Independence of the Vice Presidency," Legislation and Public Policy 17 (2014): p. 302-306.

22 Brownell, "The Independence of the Vice Presidency" p. 355-356.

23 The only way to remove a Vice President is through impeachment .

24 Adler, David Grey, "George W. Bush as Commander in Chief: Toward the Nether World of Constitutionalism," Presidential Studies Quarterly 36 (2006): p. 530.

25 Rudalevige, Andrew, "The Decline (and Resurgence) of Congress: Charting a New Imperial Presidency," Presidential Studies Quarterly 36 (2006): p. 511-512. See also Whittington, Keith E. and Daniel P. Carpenter, "Executive Power in American Institutional Development," Perspectives in Politics 1 (2003): p. 495-513. 
coupled with a general reluctance of Congress to oppose the White House on national security. ${ }^{26}$

One might think that Bush would have kept that power for himself, instead of delegating it to his sidekick. For reasons outlined in further detail below, however, the President was willing to delegate many national security responsibilities to Cheney. Bush gave Cheney powers in other, domestic policy areas as well, but the expansion of national security powers in such areas as surveillance and the fight against weapons of mass destruction meant that delegation was necessary. ${ }^{27}$ There was also a legal precedent. As Vice President in 1961, Lyndon B. Johnson asked the Assistant Attorney General to study the powers of the Vice President in the executive branch. The surprising answer is that it is the President's decision on how much power to delegate, but that the Vice President has much more legitimacy in foreign affairs and national security than in domestic politics. ${ }^{28}$

James P. Pfiffner claimed in 2009 that: "In the George W. Bush administration... national security advice to the president was dominated by Vice President Cheney." ${ }^{29}$ Joel Goldstein said that Cheney was the "Chief Operating Officer" to President Bush's CEO, and that "Vice President Cheney has been seen as the architect of virtually every significant initiative of the administration." ${ }^{30}$ How did Cheney come to be such a powerful sidekick in the Bush administration?

Cheney was far from an unknown figure in Washington, despite his reputation for operating in the shadows. He began his political career in 1968 as an American Political Science Association congressional fellow, and was initially rejected for a job by Donald Rumsfeld, who at the time was a congressman from Illinois. ${ }^{31}$ After the rejection, however, Cheney later became Rumsfeld's employee and colleague, and the two men worked closely together during the Ford administration. Cheney became Chief of Staff when Rumsfeld gave up the position to become Secretary of Defense in 1975. Cheney's career continued after Ford's defeat, and he was elected as a Republican Representative from Wyoming for ten years during the 1980s. President George H.W. Bush then appointed Cheney as his Secretary of Defense during the Persian Gulf War.

26 Hess, Gary R., "Presidents and the Congressional War Resolutions of 1991 and 2002," Political Science Quarterly 121 (2006): p. 109-110.

27 Baumgartner, Jody C., The American Vice Presidency: From the Shadows to the Spotlight (Lanham: Rowman \& Littlefield, 2015): p. 163-164, 168.

28 Katzenbach, Nicolas, Assistant Attorney General, Office of Legal Counsel, "Participation of the Vice President in the Affairs of the Executive Branch," Memorandum Opinion for the Vice President, 19 Mar. 1961.

29 Pfiffner, James P., "The Contemporary Presidency: Decision Making in the Bush White House," Presidential Studies Quarterly 39 (2009): p. 366.

30 Goldstein, "The Rising Power of the Modern Vice Presidency": p. 384.

31 Cheney and Cheney: p. 41. 
Cheney's experience in the White House and in the Pentagon was valuable for President George W. Bush, who came to the White House with little experience in the fields of foreign policy and national security, and delegated much of that authority to Cheney. ${ }^{32}$ In this sense, according to Goldstein, Cheney was powerful fundamentally because Bush decided it would be so. ${ }^{33}$ Interestingly, however, in his memoirs, President Bush says that he was pleased to have Cheney as Vice President, due to his "pro-life, low-tax positions [which] helped cement key parts of our base," which were domestic issues. ${ }^{34}$ Cheney was clearly the sidekick of Bush, but at the same time, as we will see below, Bush allowed him to have so much responsibility in foreign policy, that Cheney effectively became the leader in the issue area.

One claim is that Cheney became so powerful because he had no ambition to be president, and thus was not a threat to Bush. The White House Chief of Staff in the first Bush term, Andrew Card, stated that: "The vice president is not looking to be president. Do you know how unusual that is?" 35 The fundamental problem with this argument was that Cheney in fact did want to be president during the 1990s, and even began to set up a campaign for a run in 1996. Cheney stated in his memoirs in 2011: "The idea of serving as president was very appealing. I had worked in the White House or served in the cabinet of three presidents. And I believed I knew what it takes to make an effective chief executive." ${ }^{36}$ Cheney had more ambition than is commonly believed, and it is very likely that Bush and other White House officials would have known this at the time. Cheney admits that the run for president would have been a "long-shot prospect" and that he was worried about his family and his history of heart problems. ${ }^{37}$

If Cheney thought himself unfit to become President, then how did he become Vice President? There is a fairly extensive literature on how the Vice President is selected in American politics, and recent scholarship suggests that it is important for Presidents to choose running mates who have a great deal of experience in government. ${ }^{38}$ Earlier hypotheses, which indicated that the Vice President was chosen for "ticket balancing," or providing a particular political advantage (the electoral votes of a large state, or an alliance with another faction of the party), have lost significance since the election reforms

32 Goldstein, "The Rising Power of the Modern Vice Presidency" p. 385, Relyea p. 335-336.

33 Goldstein, "The Rising Power of the Modern Vice Presidency" p. 386.

34 George W. Bush, Decision Points (New York: Broadway Books, 2011): p. 70.

35 Cited in Bumiller and Schmitt.

36 Cheney and Cheney: p. 241-242.

37 Cheney and Cheney: p. 242, 246, 254.

38 Hiller, Mark and Kriner, Douglas, "Institutional Change and the Dynamics of Vice Presidential Selection,” Presidential Studies Quarterly 38 (2008): p. 402. 
of the early 1970s. ${ }^{39}$ The three electoral votes in the state of Wyoming make it improbable that Bush would have chosen Cheney to balance the ticket in 2000.40

There is a good deal of controversy regarding Cheney's selection as Vice President. Cheney was in charge of the Bush administration's committee to find a running mate in 2000, and he interviewed the other candidates himself. A number of commentators claim that Cheney's intention all along was to appoint himself Vice President, by using his position to eliminate other contenders. ${ }^{41}$ With current sources, it is not possible to make a definitive statement on this question, but recent scholars argue that Cheney at least made a deal with Bush for more power if he agreed to be Vice President. ${ }^{42}$ A detailed CNN report on Cheney's selection prior to the 2000 election stated at the time that Bush had a great deal of trust in Cheney, which would help explain the delegation of extensive powers to the President's sidekick after the election. ${ }^{43}$

A further reason for the unprecedented scope of Cheney's power was the concentration of national power in the executive branch in the Bush administration. The attempt to gain more power for the executive at the expense of Congress had been in the works since the 1970s after the reduction of presidential power following Watergate. ${ }^{44}$ Cheney was at the forefront of this effort prior to $2000 .{ }^{45}$ In what is perhaps the most prominent example of Cheney's belief in the importance of executive power, he, as a Congressman in 1987, co-wrote a "Minority Report," defending President Ronald Reagan against the Congressional majority in the Iran-Contra affair. ${ }^{46}$ After the 2000 elections, Cheney even went so far as to at least indirectly claim executive privilege for the Vice President to keep secrets in dealing with Congress, which was a long way from the limited legislative role for the office envisaged by the Founders. ${ }^{47}$ The first attempt to work outside of Congress was Cheney's

39 Hiller and Kriner: p. 405.

40 Baumgartner: p. 159.

41 Fisman, David, Fisman, Raymond J., Galet, Julia, Khurana, Rakesh, and Wang, Yongxiang, "Estimating the Value of Connections to Vice-President Cheney," B.E. Journal of Economic Analysis and Policy 13 (2012): p. 6.

42 Baumgartner: p. 159.

43 Carney, James and Dickerson, John F., "How Bush Decided," CNN, 1 Aug. 2000.

44 Skowronek, Stephen, "The Conservative Insurgency and Presidential Power: A Developmental Perspective on the Unitary Executive," Harvard Law Review 122 (2009): p. 2070-2103.

45 Meiers, Franz-Josef, "The Return of the Imperial Presidency? The President, Congress, and US Foreign Policy after 11 September 2001," Amerikastudien/American Studies 55 (2010): p. 255.

46 For the text of this report, see United States, Cong., "Report of the Congressional Committees Investigating the Iran-Contra Affair with Supplemental, Minority, and Additional Views," (Washington DC, 17 November 1987): p. 431-633.

47 Brownell, Roy E., "Vice Presidential Secrecy: A Study in Comparative Constitutional Privilege and Historical Development," St. John's Law Review 84 (2010): p. 539-540. 
claim to secrecy for the minutes of meetings of a new energy task force in $2001 .{ }^{48}$ The growth of Cheney's power in early 2001 undermines the claim that Cheney's exceptional responsibilities were due to the 9/11 attacks.

\section{Cheney, Rumsfeld and Decision-Making on Iraq}

While Cheney's expertise in foreign policy, Bush's decision to give him more power, and the expansion of executive powers in foreign policy after 9/11 contributed to the scope of his influence, an under-explored element is Cheney's relationship with other members of the Bush administration. In a review of the memoirs of Bush's advisors in 2013, historian Melvyn Leffler argued that "None doubted that Bush was, in fact, the decision-maker." 49 Cheney was a close advisor, but not the one calling the shots, at least most of the time, considering the order given on 11 September mentioned above. ${ }^{50}$ Even if Bush ultimately made the final decisions in foreign policy or in national security, Cheney wielded considerable power on the Bush team. Cheney could not have done this alone, however, and was helped a great deal by Secretary of Defense Donald Rumsfeld.

Cheney was in charge of the transition in 2000, which meant that he had at least some influence over who was hired for key cabinet positions. Cheney interviewed in particular the candidates for Secretary of Defense alongside Bush, and said Rumsfeld was appointed because he "outperformed the others in his interview." ${ }^{11}$ He lauded in particular Rumsfeld's experience and vision for the military. ${ }^{52}$ Shirley Anne Warshaw wrote that Cheney was really not directly in charge of hiring decisions, however, and that Andrew Card handled that part of the transition. ${ }^{53}$ It is clear, however, that Cheney was able to exert important influence over the choice of White House officials, due to his closeness to Bush. Rumsfeld, in his memoirs, seems to have had nothing but the highest respect for Cheney, saying that he "was uniquely influential as a vice president because he thought systematically, did his homework, and presented his ideas with skill, credibility, and timelines." ${ }^{4}$

48 Montgomery, Bruce P., "Congressional Oversight: Vice President Richard B. Cheney's Executive Branch Triumph,” Political Science Quarterly 120 (2005/2006): p. 582.

49 Leffler, Melvyn P., "The Foreign Policies of the George W. Bush Administration: Memoirs, History, Legacy," Diplomatic History 37 (2013): p. 211.

50 Leffler: p. 211.

51 Cheney and Cheney: p. 299.

52 Cheney and Cheney: p. 299.

53 Warshaw, Shirley Anne, Guide to the White House Staff(Thousand Oaks, CA: CQ Press, 2013): p. 186.

54 Rumsfeld, Donald, Known and Unknown: A Memoir (New York: Sentinel Trade, 2012): p. 320. 
As the White House is a highly complicated organization, Cheney was able to use the bureaucratic dynamics to his own advantage, at least in Bush's first term. James Pfiffner has argued that Cabinet secretaries have seen their power increasingly challenged by the large number of White House staff. ${ }^{55}$ Cheney increased his own staff, which became very powerful, and at least partially duplicated the NSC, allowing the Vice President to create his own separate policymaking structure that shut out rival Cabinet members. ${ }^{56}$ The Vice President's staff was present at every level of the policymaking process, monitoring and intervening in events. ${ }^{57}$ While the details of bureaucratic infighting in the Bush White House will not be known for many years, it is probable that Cheney used his extensive knowledge of that bureaucracy from his previous experience to maximize his power over the rest of the Cabinet.

It appears that Rumsfeld and Cheney were able to largely dominate White House decision-making on national security between 2001 and 2006. As is well known, for Iraq policy and counter-terrorism, Bush relied on a small group of advisors, which included Cheney, Rumsfeld, Cheney's Chief of Staff Lewis Libby, National Security Advisor Condoleeza Rice, Secretary of State General Colin Powell, Deputy Defense Secretary Paul Wolfowitz, and CIA Director George Tenet. ${ }^{58}$ Aside from Cheney and Rumsfeld, Rice and Powell were the most important members of the team for the decision to go to war in Iraq. Both were repeatedly attacked by Cheney and Rumsfeld so as to push their agenda through the White House decision-making process. That agenda was to overthrow Saddam Hussein, but to do it with as few troops as possible. ${ }^{59}$

Both Rumsfeld and Cheney believed that the attack on Iraq could be undertaken without the 500,000 soldiers believed necessary in the late 1990s for such a campaign. The Afghanistan War validated the theories of the Vice President and Secretary of Defense that the combination of precisionguided weapons and networked warfare, the so-called "Revolution in Military Affairs (RMA)," eliminated the need for large numbers of ground troops. Powell, a retired general, was against the plan, and skeptical of the purported successes of the RMA model in Afghanistan, but he was overruled. ${ }^{60}$ One of

55 Pfiffner, James, “Cabinet Secretaries versus the White House Staff," Brookings, 12 Mar. 2015.

56 Baumgartner: p. 163.

57 Halperin, Morton H., Clapp, Priscilla A., and Kanter, Arnold, Bureaucratic Politics and Foreign Policy, $2^{\text {nd }}$ ed. (Washington DC: Brookings Institution, 2006): p. 113. The tactic was also recommended by Elliot Abrams, a close advisor to President Bush. Abrams, Elliot, "The Prince of the White House," Foreign Policy, 12 Mar. 2013.

58 Haney, Patrick J., "Foreign-Policy Advising: Models and Mysteries from the Bush Administration," Presidential Studies Quarterly 35 (2005): p. 289-302.

59 Leffler: p. 205, 209-210.

60 Gordon, Michael R. and Trainor, Bernard E., Cobra II: The Inside Story of the Invasion and Occupation of Iraq (New York: Knopf Doubleday, 2006). For a military analysis of the problem, see Andres, Richard B., "The Afghan Model in Northern Iraq," War in Iraq: Planning and 
the reasons for why Cheney and Rumsfeld were able to get their way on this question was that President Bush agreed with their point of view on Iraq and military strategy. ${ }^{61}$ The lack of sufficient forces in Iraq at the outset of the war is seen by many analysts as one of the main reasons that the US was unable to defeat the subsequent insurgency. ${ }^{62}$

An even more controversial part of the decision to overthrow Saddam Hussein was the supposed link between Iraq and Al Qaeda. It appears that Cheney and Rumsfeld were key players in pushing the idea that Saddam was linked to the 9/11 attacks. Cheney still believed this in 2011, writing in his memoirs: "When we looked around the world in those first months after $9 / 11$, there was no place more likely to be a nexus between terrorism and WMD capability than Saddam Hussein's Iraq." ${ }^{63}$ Wolfowitz also believed that it was true. ${ }^{64}$ In 2004, Chaim Kaufmann said that Cheney was the one primarily responsible for "threat inflation" in the run-up to the Iraq War, in essence, making the threat from Iraq seem much greater than it actually was. He pressured other government agencies, including the CIA, to present intelligence in a way that favored his case for war. ${ }^{65}$ Cheney's neoconservative worldview included a fundamental belief that the strategies of deterrence and containment were ineffective, despite the lessons of the Cold War, and that threats such as $\mathrm{Al}$ Qaeda had to be engaged directly. ${ }^{66}$

Cheney focused on blocking his main adversaries in the White House, including National Security Advisor Rice. The National Security Advisor is at least in theory the main advisor for national security policy, but is not an office that exists in the constitution. A number of previous National Security Advisors had been powerful players in the government, especially Kissinger. President Bush liked and respected Rice, but Cheney, Rumsfeld, and Powell did not attempt to work closely with her on many issues, including on Iraq. ${ }^{67}$ As for Powell, both Rumsfeld and Cheney worked to undermine

Execution, Mahnken (ed.), Thomas G. and Keaney, Thomas A. (Abingdon: Routledge, 2007): p. 52-68.

61 Gordon, Michael R. and Trainor, Bernard E., The Endgame: The Inside Story of the Struggle for Iraq, From George W. Bush to Barack Obama (New York: Random House, 2012): p. 5-14. See also Metz, Steven and Martin, John R., Decisionmaking in Operation Iraqi Freedom: Removing Saddam Hussein by Force (Carlisle Barracks, PA:US Army War College, Strategic Studies Institute, February 2010): p. 7-8.

62 Bensahel, Nora "Mission not accomplished," War in Iraq: Planning and Execution, Mahnken and Keaney (ed.) (Abingdon: Routledge, 2007): p. 138.

63 Cheney and Cheney: p. 368.

64 Leffler: p. 201.

65 Kaufmann, Chaim, "Threat Inflation and the Failure of the Marketplace of Ideas: The Selling of the Iraq War," International Security, 29 (2004): p. 20, 37, 39.

66 Metz and Martin, Decisionmaking in Operation Iraqi Freedom: Removing Saddam Hussein:p. 22.

67 Daalder, Ivo H. and Destler, I.M., "In the Shadows of the Oval Office: The Next National Security Advisor," Foreign Affairs 88 (2009): p. 125-126. 
the power of the State Department in favor of Defense, and Powell sometimes only found out about Cheney's decisions regarding national security on the news. ${ }^{68}$ When Powell contradicted Cheney on bringing weapons inspectors back to Iraq in 2002, he was accused of "disloyalty" to the President, indicating the extent to which Cheney directly represented Bush's interests. ${ }^{69}$

As Cheney worked on dominating White House policymaking, Rumsfeld stifled opposition from certain parts of the US military regarding Iraq policy. Rumsfeld's direct and aggressive control of the military establishment was at least one of the reasons leading to his resignation in 2006 after the so-called "revolt of the generals." ${ }^{\prime}$ As cited by James Pfiffner, Powell's Chief of Staff James Wilkerson called the relationship between Rumsfeld and Cheney a "cabal" in which they made all major national security decisions. ${ }^{71}$

\section{A Decline in Vice-Presidential Power? After Rumsfeld}

Cheney's power was at its zenith with the decision to invade Iraq, and he supported initiatives for enhanced interrogation techniques and military tribunals for prisoners associated with terrorist groups. It must be noted that Cheney was not the only one in favor of these measures, as Rice, Rumsfeld, Powell, Tenet and Attorney General John Ashcroft also approved. ${ }^{72}$ The debate over enhanced interrogation resurfaced at the end of 2014, with the release of the Senate Intelligence Committee's report on CIA interrogation techniques. The report cites Cheney a number of times and indicates that he was briefed extensively about the CIA's interrogation program. ${ }^{73}$ While the report does not indicate who made decisions about the program, statements include that "on July 29, 2003, the CIA made a presentation to a select group of National Security Council principals, including Vice President Cheney, seeking policy reaffirmation of the CIA interrogation program." " ${ }^{34}$ Cheney subsequently claimed that the Senate Report was "deeply flawed," and said that President Bush knew all about the CIA interrogation program. ${ }^{75}$

68 Pfiffner, "The Contemporary Presidency": p. 371, 380.

69 Halperin, et al.: p. 186.

70 Owens, Mackubin Thomas, "What Military Officers Need to Know About Civil-Military Relations," Naval War College Review 65 (2012): p. 68.

71 Pfiffner, James P., “The First MBA President: George W. Bush as Public Administrator," Public Administration Review 67 (2007): p. 8.

72 Ehrenberg, John, McSherry, J. Patrice, Sanchez, José Ramon and Marji Sayej, Caroleen, eds., The Iraq Papers (Oxford: Oxford University Press, 2010): p. 410.

73 United States, Cong., Senate, Select Committee on Intelligence, Committee Study of the Central Intelligence Agency's Detention and Interrogation Program (Washington DC: US Senate, 3 December 2014): p. 228, 241. Cheney's name appears 44 times (by this author's count).

74 United States, Cong., Senate p. 353.

75 "Cheney defends CIA interrogation techniques, calls Senate report 'deeply flawed," Fox News 11 Dec. 2014. 
There were setbacks, however, starting in summer 2003. The Valerie Plame affair, where the identity of a CIA agent was leaked to the press in retaliation for an attack in the newspaper on the administration by her husband, embarrassed Cheney's office. His top aide, Libby, eventually took the fall for the affair, but Cheney in his memoirs blamed Richard Armitage, the Deputy Secretary of State. ${ }^{76}$ While the details remain unclear, what is probable is that Cheney's accusation of Armitage indicated a continued desire to undermine the power of the State Department in favor of Defense.

Another, more pressing problem for Cheney was the problems in the Iraq War. Cheney says in his memoirs that Rumsfeld attempted to resign over torture at Abu Ghraib prison in 2004, but that Bush stopped him, saying he could not resign during the war. ${ }^{77}$ In November 2006, however, with midterm elections looming amid the disaster in Iraq, Rumsfeld became a liability for the White House, and President Bush asked him to resign. ${ }^{78}$ Bob Woodward goes fairly easy on Rumsfeld, whereas other analysts say that his treatment of the armed forces and senior officers had become untenable. ${ }^{79}$ Stephen Metz stated that Bush fired Rumsfeld so as to attribute the blame to his Secretary of Defense for the failed strategy in Iraq. ${ }^{80}$

Rumsfeld's departure appears to have isolated Cheney a great deal in the Bush Administration. Much of the analysis claiming Cheney was in charge of the country appeared during this period, but it was really when his influence was declining. His reputation as a Republican hardliner hampered the Vice President's ability to make policy after the GOP setback in the 2006 elections. ${ }^{81}$ Rice also gained more power than before in national security, and Bush appears to have started to listen more to the State Department. ${ }^{82}$ Rather than a direct reaction against Cheney, his loss of power and influence appears to have had a great deal to do with sanctioning Rumsfeld's policies, which indicates that many in the administration believed that Rumsfeld had done considerable damage. Rumsfeld's departure was of course not the only reason, and Jody Baumgartner has recently argued that Cheney's decrease in influence in the second term was largely due to his unpopularity with the public. ${ }^{83}$

76 Cheney and Cheney: p. 407.

77 Cheney and Cheney: p. 421.

78 Woodward, Bob, The War Within: A Secret White House History, 2006-2008 (London: Pocket Books, 2008): p. 194-197.

79 Feaver, Peter D., "The Right to be Right: Civil-Military Relations and the Iraq Surge Decision," International Security 35 (2011): p. 97-98.

80 Metz, Steven and Martin, John R., Decisionmaking in Operation Iraqi Freedom: The Strategic Shift of 2007 (Carlisle Barracks, PA: US Army War College: Strategic Studies Institute, May 2010): p. 43-44.

81 Pressman, Jeremy, "Power Without Influence: The Bush Administration's Foreign Policy Failure in the Middle East," International Security 33 (2009): p. 175.

82 Goldstein, “The Contemporary Presidency": p. 133-134.

83 Baumgartner: p. 170. 
Cheney, despite his association with Rumsfeld and the failures of the Iraq War, retained some influence, as Bob Woodward points out that senior generals used Cheney as a conduit to contact Bush outside of the chain of command for proposals for sending more soldiers to Iraq in the 2007 Surge. ${ }^{84}$ While it remains difficult to identify clearly Cheney's role in the Surge decision, he was in direct contact with military officers in the discussions over sending more troops, which indicates a close relationship, and more generally, support from the military ${ }^{85}$ Cheney was in favor of the Surge strategy, and made an effort to support General Jack Keane's (the strategy's foremost advocate) ideas with President Bush. ${ }^{86}$ Metz and Martin indicate that Cheney "likely played a major role," but would never have gone against any of the President's decisions regarding Iraq. ${ }^{87}$

Cheney's relationship with the new Secretary of Defense, Robert Gates, was much less close than that with Rumsfeld. Gates was generally praised for having improved civil-military relations after the problems between Rumsfeld and the senior officers during 2005 and $2006 .{ }^{88}$ Gates had a good deal of respect for Cheney, as did Rumsfeld, but did not have the close working relationship developed over years. He claims that the torture issue and Guantanamo led Cheney to become more "isolated within the senior ranks of the administration," but that he was very calm, and not the "Darth Vader" of his reputation. ${ }^{89}$ Gates does indicate, however, that he blocked Cheney's agenda for a military confrontation with Iran. ${ }^{90}$ Without going into why, Gates makes an interesting comment at the end of his memoirs, saying that "By early 2007, Vice President Cheney was the outlier on the team, with Bush, Rice, Hadley [Steven Hadley, the National Security Advisor], and me in broad agreement on virtually all important issues." ${ }^{11}$

\section{Conclusion}

Cheney's isolation and loss of influence after 2006 merits further research as more source material becomes available. It is probable that the departure of Rumsfeld as well as the continued impopularity after Iraq had a good deal to do with Cheney's decline, but the extent of that decline and its nature remains unclear.

84 Woodward, The War Within: p. 331.

85 Woodward, The War Within: p. 356.

86 Cheney and Cheney: p. 450-451.

87 Metz and Martin, Decisionmaking in Operation Iraqi Freedom: The Strategic Shift: p. 26.

88 Owens: p. 68-69.

89 Gates, Robert M., Duty: Memoirs of a Secretary at War (London: WH Allen, 2014): p. 98.

90 Gates: p. 98.

91 Gates: p. 584. 
Cheney was the most powerful Vice President in American history. While he may not have been the leader of the country, he had substantial influence with Bush and over national security policy in general. He was able to bolster this power both through a powerful staff that created a new power structure in the White House and through his alliance with his one-time mentor Donald Rumsfeld. This association allowed the two men to dominate the policy-making process by marginalizing their less powerful colleagues on the Bush foreign policy team. Bush also appears to have given his approval to this arrangement, delegating powers to his sidekick that often made Cheney the number one power in foreign and defense policy.

Can Cheney's model be replicated? Gates told Joe Biden to follow Cheney's model as Obama's Vice President, and Biden certainly had the political experience and foreign policy experience to do so. ${ }^{92}$ Biden is viewed often by the media as largely ineffectual, but a number of analytical articles about his relationship with Obama and his power in the administration indicate otherwise. Biden is taken more seriously than commonly believed. ${ }^{93}$ Despite certain military officers' open dislike of Biden, he played an important role during the decision to surge more soldiers to Afghanistan in 2009. ${ }^{94}$ When General Stanley McChrystal's staff publicly insulted Biden in a Rolling Stone article in 2010, Obama removed the general, who was the commander of US forces in Afghanistan. ${ }^{95}$ Biden is clearly seen as less of a formidable power than Cheney, however. More research remains to be done on comparing the performance of Cheney and Biden to show how the Vice Presidency has evolved to become the most important sidekick of the President over the last fifteen years.

Christopher Griffin

TRENDS Research \& Advisory, Abu Dhabi Non-Resident Fellow Strategic Studies and Counterinsurgency cwgriffi@yahoo.fr

92 Gates: p. 282-283.

93 Hirsh, Michael, "Joe Biden: The Most Influential Vice President in History?" The Atlantic 31 Dec. 2012, Viser, Matt, "Gaffes aside, Joe Biden a power in White House," Boston Globe 19 Jan. 2013, Osnos, Evan, “The Biden Agenda," The New Yorker, 28 Jul. 2014.

94 Woodward, Bob, Obama's Wars (London: Simon and Schuster, 2010).

95 Wilson, Scott and Shear, Michael D., "Gen. McChrystal is dismissed as top US commander in Afghanistan,” Washington Post, 24 Jun. 2011. 


\begin{abstract}
Richard Cheney was the most powerful Vice President in American history. His influence was primarily concentrated in the arena of national security policy. This article examines how Cheney was able to marshal unprecedented influence in the context of both the greater increase in vice presidential power since 1945 and the decision-making structure of the Bush Administration. A largely unexplored reason for Cheney's influence was his close working relationship with Secretary of Defense Donald Rumsfeld, which allowed the two men to dominate the White House policymaking team on Iraq and counterterrorism policy.
\end{abstract}

\title{
Keywords
}

United States Vice-President, George W. Bush, Richard Cheney, Donald Rumsfeld, United States foreign policy, United States defense policy.

\section{Résumé}

Richard Cheney est le vice-président le plus puissant dans l'histoire américaine, et a exercé une emprise toute particulière sur la sécurité nationale. Cet article examine comment Cheney a pu prendre une telle influence, dans le contexte d'une évolution du pouvoir des vice-présidents depuis 1945 ainsi que de la structure décisionnelle de l'administration Bush. L'influence majeure de Cheney sur la politique américaine tient également à sa relation avec le secrétaire de Défense Donald Rumsfeld. Ce partenariat a permis aux deux hommes de dominer l'équipe de la Maison Blanche en pesant sur les décisions relatives à la guerre en Irak et à la guerre contre le terrorisme.

\section{Mots-clés}

Vice-Président des États-Unis, George W. Bush, Richard Cheney, Donald Rumsfeld, politique étrangère des États-Unis, politique de défense des États-Unis. 